Chem. Pharm. Bull.

36( 8$) 3043-3048(1988)]$

\title{
Metabolism of Paeoniflorin and Related Compounds by Human Intestinal Bacteria. IV. Formation and Structures of Adducts of a Metabolic Intermediate with Sulfhydryl Compounds by Lactobacillus brevis
}

\author{
Teruaki Akao, ${ }^{a}$ Yue-Zhong Shu, ${ }^{b}$ Yoko Matsuda,${ }^{a}$ Masao Hattori,${ }^{b}$ \\ TSUNEO NAMBA ${ }^{b}$ and KYOICHI KOBASHI ${ }^{*, a}$ \\ Faculty of Pharmaceutical Sciences ${ }^{a}$ and Research Institute for Wakan-Yaku \\ (Oriental Medicines), ${ }^{b}$ Toyama Medical and Pharmaceutical University, \\ 2630 Sugitani, Toyama 930-01, Japan
}

(Received January 25, 1988)

\begin{abstract}
Paeoniflorin from peony roots was converted to new compounds in the presence of various sulfhydryl compounds by Lactobacillus brevis. The compounds formed in the presence of 3mercaptopropionic acid, 2-mercaptoethanol and thiobenzoic acid were determined to be $7 R$ and $7 S$ mixture of 8-(2-carboxyethylthio)paeonimetabolin I, 8-(2-hydroxyethylthio)paeonimetabolin I and 8-benzoylthiopaeonimetabolin I, respectively, by various spectroscopic methods. These compounds are adducts of a metabolic intermediate of paeoniflorin with the sulfhydryl compounds.
\end{abstract}

Keywords-8-(2-hydroxyethylthio)paeonimetabolin I; 8-(2-carboxyethylthio)paeonimetabolin I; 8-benzoylthiopaeonimetabolin I; human intestinal bacteria; metabolism; paeoniflorin; Lactobacillus brevis

During the course of our studies on the metabolism of paeoniflorin (1) and related compounds from Paeoniae Radix by human intestinal bacteria, we found that $\mathbf{1}$, as well as oxypaeoniflorin and benzoylpaeoniflorin, was converted to various metabolites by human intestinal flora. ${ }^{1)}$ The structure of the major metabolite was concluded to be $7 \mathrm{~S}$ paeonimetabolin I (2), ${ }^{2)}$ and possible metabolic processes from 1 to 2 were proposed. Many defined strains of human intestinal bacteria such as Lactobacillus brevis and Bacteroides fragilis were able to metabolize 1 to a mixture of $7 S$ - and $7 R$-paeonimetabolins I ( 2 and $\mathbf{3}$, respectively), ${ }^{3,4)}$ and the structure of the latter was confirmed by $\mathrm{X}$-ray analysis. ${ }^{3)}$

In the present paper, we report the formation of adducts of a metabolic intermediate and sulfhydryl compounds during incubation of 1 with $L$. brevis in the presence of sulfhydryl compounds, and the characterization of these adducts by various spectroscopic methods.

\section{Materials and Methods}

Instruments - - Infrared (IR) spectra were measured with a Hitachi 260-10 infrared spectrophotometer. Proton and carbon-13 nuclear magnetic resonance $\left({ }^{1} \mathrm{H}\right.$ - and $\left.{ }^{13} \mathrm{C}-\mathrm{NMR}\right)$ spectra were measured with JEOL FX-270 $\left({ }^{1} \mathrm{H}\right.$, $270 \mathrm{MHz})$ and JEOL-FX 90Q $\left({ }^{13} \mathrm{C}, 22.5 \mathrm{MHz}\right) \mathrm{NMR}$ spectrometers. In ${ }^{13} \mathrm{C}-\mathrm{NMR}$ spectra, the multiplicities were determined on the basis of off-resonance decoupling (OFR) and insensitive nuclei enhanced by polarization transfer (INEPT) techniques. Tetramethylsilane was used as an internal standard in all the measurements. Mass spectra (MS) were measured with a JEOL D-200 mass spectrometer at an ionization voltage of $70 \mathrm{eV}$. High-performance liquid chromatography (HPLC) was carried out on Tri-Rotar SR-1 equipped with a UVIDEC-100-IV detector (JASCO).

Materials_-Paeoniflorin was isolated from peony roots according to the method of Kaneda et al..$^{5}$ GAM broth was a product of Nissui Seiyaku Co., Ltd. (Tokyo). All chemicals used were of analytical reagent grade.

Chromatography of Metabolites-Wakogel C-200 was used for column chromatography. Thin layer chromatography (TLC) was performed on Merck Kieselgel $60 \mathrm{~F}$ or Merck PSC-60 F (for preparative purposes) plates with a 
solvent system of $\mathrm{CHCl}_{3}-\mathrm{MeOH}$-benzene $(5: 2: 1)$. Spots on the plates were visualized by exposure to iodine vapor or by spraying with an anisaldehyde- $\mathrm{H}_{2} \mathrm{SO}_{4}$ reagent, followed by heating.

Metabolism of Paeoniflorin by Lactobacillus brevis in the Presence of Sulfhydryl Compounds_ A bacterial suspension of $L$. brevis precultured overnight in an anaerobic box was added to 9 vol. of GAM broth and cultivated for $5 \mathrm{~h}$ at $37^{\circ} \mathrm{C}$ in the anaerobic box. The cells obtained by centrifugation at $7000 \mathrm{rpm}$ for 10 min were washed once with a saline solution and suspended in $1 / 40$ of the culture volume of $50 \mathrm{~mm}$ potassium phosphate buffer ( $\mathrm{pH} 7.2)$. The reaction mixture contained $0.2 \mathrm{ml}$ of the bacterial suspension, $40 \mu \mathrm{l}$ of $17 \mathrm{~mm}$ paeoniflorin solution and $0.2 \mathrm{ml}$ of $50 \mathrm{~mm}$ potassium phosphate buffer ( $\mathrm{pH}$ 7.2). A sulfhydryl compound was added to the reaction mixture at a final concentration of $5 \mathrm{~mm}$. After incubation for $1 \mathrm{~h}$ at $37^{\circ} \mathrm{C}$, the reaction was stopped by adding $0.8 \mathrm{ml}$ of butanol and then extracted. An aliquot of the butanol layer was chromatographed on a silica gel TLC plate with the solvent system described above.

Isolation of $\mathbf{7} \boldsymbol{R}$ - and $\mathbf{7 S - 8}$-(2-Carboxyethylthio)paeonimetabolins $\mathbf{I}-\mathrm{A}$ precultured bacterial suspension $(600 \mathrm{ml})$ of $L$. brevis was added to GAM broth $(6 \mathrm{l})$ and cultivated for $12 \mathrm{~h}$ at $37^{\circ} \mathrm{C}$. The culture was centrifuged at $7000 \mathrm{rpm}$ for $10 \mathrm{~min}$. The precipitates were washed with a saline solution, centrifuged and suspended in $50 \mathrm{~mm}$ phosphate buffer $(900 \mathrm{ml})$. The suspension was transferred into six tubes. 3-Mercaptopropionic acid $(500 \mathrm{mg}) \mathrm{and}$ then paeoniflorin $(1,1.2 \mathrm{~g})$ were added to each tube. The mixture was anaerobically incubated for $4 \mathrm{~h}$ at $37^{\circ} \mathrm{C}$ and adjusted to $\mathrm{pH} c a .4$ with dilute $\mathrm{HCl}$, then extracted three times with ethyl acetate (AcOEt, $200 \mathrm{ml}$ each). The organic layer was washed with a saturated $\mathrm{NaCl}$ solution, and concentrated in vacuo to give an oily residue. The combined residues $(0.6 \mathrm{~g})$ were applied to a column of silica gel $(60 \mathrm{~g}, 24 \times 240 \mathrm{~mm})$. The column was thoroughly washed with $\mathrm{CHCl}_{3}$ and eluted with $\mathrm{CHCl}_{3}-\mathrm{MeOH}(100: 2)$. Fractions ( $30 \mathrm{ml}$ each) were collected and monitored by TLC and ${ }^{1} \mathrm{H}-$ NMR. Fractions $1-3$ afforded a colorless oil $(4,20 \mathrm{mg})$ and fractions $14-20$ an oil $(5,15 \mathrm{mg})$. Fractions 4-13 gave a mixture of 4 and 5 (48 $\mathrm{mg})$.

7S-8-(2-Carboxyethylthio)paeonimetabolin I (4)—CColorless oil. High-resolution MS: Found, 302.0859, Calcd for $\mathrm{M}^{+}, \mathrm{C}_{13} \mathrm{H}_{18} \mathrm{O}_{6} \mathrm{~S}, 302.0824$. IR $v_{\max }^{\mathrm{KBr}} \mathrm{cm}^{-1}: 3400$ (br, OH), $1720(\mathrm{br}, \mathrm{C}=\mathrm{O})$. MS m/z (rel. int): $302\left(\mathrm{M}^{+}, 2\right), 284(2)$, 266 (6), $248(2), 197(20), 178(56), 161(50), 151(76), 121(30), 106(78), 88(63), 69(100)$.

7R-8-(2-Carboxyethylthio)paeonimetabolin I (5)_Colorless oil. High-resolution MS: Found, 302.0838, Calcd for $\mathrm{M}^{+}, \mathrm{C}_{13} \mathrm{H}_{18} \mathrm{O}_{6} \mathrm{~S}, 302.0824$. MS $m / z$ (rel. int): $302\left(\mathrm{M}^{+}, 2\right), 284(4), 266(10), 197$ (15), 178 (100), 161 (74), $150(83)$, $121(54), 106(83), 88(64), 77(64), 69(88)$.

Isolation of $7 \boldsymbol{R}$ - and $7 \boldsymbol{S}$-8-(2-Hydroxyethylthio)paeonimetabolins I-Paeoniflorin $(\mathbf{1}, 1.2 \mathrm{~g})$ was incubated with a suspension of L. brevis $(900 \mathrm{ml})$ in the presence of 2-mercaptoethanol $(370 \mathrm{mg})$ under conditions similar to those described above. The products were extracted with AcOEt without acidification. The organic layer was evaporated in vacuo to give an oily residue $(0.5 \mathrm{~g})$. The residue was chromatographed on a silica gel column $(60 \mathrm{~g}, 24 \times 240 \mathrm{~mm})$. The column was washed with $\mathrm{CHCl}_{3}$ and eluted with $\mathrm{CHCl}_{3}-\mathrm{MeOH}(100: 0.7)$. Fractions $(40 \mathrm{ml} / \mathrm{flask})$ were collected and monitored by TLC and ${ }^{1} \mathrm{H}-\mathrm{NMR}$. Fractions $24-27,28-39$ and $40-44$ afforded 6 (colorless oil, $19 \mathrm{mg}$ ), a mixture of 6 and 7 (oil, $38 \mathrm{mg}$ ) and 7 (oil, $13 \mathrm{mg}$ ), respectively.

7S-8-(2-Hydroxyethylthio)paeonimetabolin I (6)_CColorless oil. High-resolution MS: Found, 274.0859; Calcd for $\mathrm{M}^{+}, \mathrm{C}_{12} \mathrm{H}_{18} \mathrm{O}_{5} \mathrm{~S}, 274.0874$. IR $\cdot v_{\max }^{\mathrm{KBr}} \mathrm{cm}^{-1}: 3420(\mathrm{OH}), 1720(\mathrm{C}=\mathrm{O}) . \mathrm{MS} m / z($ rel. int $): 274\left(\mathrm{M}^{+}, 3\right), 256(12), 197$ (15), $151(83), 123(10), 69(100)$.

7R-8-(2-Hydroxyethylthio)paeonimetabolin I (7)_CColorless oil. High-resolution MS: Found, 274.0857, Calcd for $\mathrm{M}^{+}, \mathrm{C}_{12} \mathrm{H}_{18} \mathrm{O}_{5} \mathrm{~S}, 274.0874$. MS m/z (rel. int): 274 (M+ $\mathrm{M}^{+}$), 256 (15), 197 (28), 151 (89), 123 (9), 69 (100).

Isolation of $7 \boldsymbol{R}$ - and $7 S$-8-Benzoylthiopaeonimetabolins $\mathrm{I}$-Paeoniflorin $(1,2.05 \mathrm{~g})$ was incubated with a suspension of L. brevis $(900 \mathrm{ml})$ in the presence of thiobenzoic acid $(1.7 \mathrm{~g})$ under conditions similar to those described above. The AcOEt extract ( $1.35 \mathrm{~g})$ was subjected to column chromatography on silica gel $(70 \mathrm{~g}, 24 \times 260 \mathrm{~mm})$. Elution with benzene- $\mathrm{CHCl}_{3}(3: 1)$ afforded a mixture $(140 \mathrm{mg})$ of compounds 8 and 9 in a ratio of $6: 4$. A portion of the mixture $(50 \mathrm{mg})$ was separated into $8(14 \mathrm{mg})$ and $9(6 \mathrm{mg})$ by preparative HPLC under the following conditions: column, Chemcosorb 5-S1, $\left(10 \mu, 10 \times 500 \mathrm{~mm}\right.$, Chemco Ltd., Osaka); mobile phase, $\mathrm{CH}_{2} \mathrm{Cl}_{2}-\mathrm{CH}_{3} \mathrm{CN}$ (100:4); flow rate, $3.5 \mathrm{ml} / \mathrm{min}$; pressure, $40 \mathrm{~kg} / \mathrm{cm}^{2}$; detection, ultraviolet (UV) at $235 \mathrm{~nm}$.

7S-8-Benzoylthiopaeonimetabolin I (8) C Colorless oil. High-resolution MS: Found, 334.0843, Calcd for $\mathrm{M}^{+}$, $\mathrm{C}_{17} \mathrm{H}_{18} \mathrm{O}_{5} \mathrm{~S}, 334.0874$. UV $\lambda_{\max }^{\mathrm{EtOH}} \mathrm{nm}(\log \varepsilon): 238(4.28), 266(4.17) . \mathrm{IR} \nu_{\max }^{\mathrm{KBr}} \mathrm{cm}^{-1}: 3420(\mathrm{br}, \mathrm{OH}), 1720(\mathrm{ketonic} \mathrm{C}=\mathrm{O})$, 1660 (thioester $\mathrm{C}=\mathrm{O}$ ). MS $\mathrm{m} / z$ (rel. int): $334\left(\mathrm{M}^{+}, 2\right), 316$ (2), 298 (4), 197 (15), 196 (25), 151 (44), 105 (90), $77(100)$, $69(51)$.

7R-8-Benzoylthiopaeonimetabolin I (9)—Colorless oil. High-resolution MS: Found, 334.0845, Calcd for $\mathrm{M}^{+}, \mathrm{C}_{17} \mathrm{H}_{18} \mathrm{O}_{5} \mathrm{~S}, 334.0874$. MS $m / z$ (rel. int): $334\left(\mathrm{M}^{+}, 1\right), 316(1), 298$ (5), 197 (16), 196 (27), 151 (46), 105 (100), $77(95), 69(49)$.

\section{Results}

New Products Formed from Paeoniflorin and Dithiothreitol by Lactobacillus brevis L. brevis suspended in phosphate buffer ( $\mathrm{pH}$ 7.2) transformed 1 to paeonimetabolin I (2 
and 3) under either aerobic or anaerobic conditions. In an attempt to isolate the metabolic intermediates, various reagents which inhibit enzyme activity were added to the bacterial suspension. The transforming activity was not affected by pretreatment with sulfhydryl reagents such as 5,5'-dithiobis-(2-nitrobenzoic acid), $p$-chloromercuriphenylsulfonic acid and $\mathrm{N}$ ethylmaleimide. However, in the presence of dithiothreitol, L. brevis transformed 1 not to paeonimetabolin I ( 2 and 3) but to new products, which showed one spot on TLC (Fig. 1). These products were found to be an isomeric mixture by ${ }^{1} \mathrm{H}$ - and ${ }^{13} \mathrm{C}-\mathrm{NMR}$. They were not produced without 1 or L. brevis even in the presence of dithiothreitol. In addition, no such products were obtained when dithiothreitol was added after transformation of $\mathbf{1}$ to paeonimetabolin I.

\section{Effects of Various Sulfhydryl Compounds on Paeoniflorin Metabolism}

The effects of other sulfhydryl compounds on the metabolism of 1 by L. brevis were examined. Addition of 1-thioglycerol, 2-mercaptoethanol, 3-mercaptopropionic acid, 2mercaptoethylamine, thiobenzoic acid and L-cysteine also resulted in the formation of new products with a corresponding decrease of 1 , little or no paeonimetabolin I ( 2 and 3 ) being produced (Fig. 2). The $R f$ values of the new products on TLC varied depending on the sulfhydryl compounds used. Moreover, the products formed in the presence of 3-mercaptopropionic acid and 2-mercaptoethylamine had higher $R f$ values with acidic and alkaline solvent systems, respectively, on TLC, but lower values in the opposite systems, showing acidic and basic properties, respectively.

Addition of glutathione (reduced form) also decreased the amounts of paeonimetabolin I ( 2 and 3 ) formed, but the new products were not extracted with butanol and remained in the aqueous layer. Similarly, the products formed in the presence of 3-mercaptopropionic acid, 2mercaptoethylamine and L-cysteine were water-soluble.

On the other hand, the addition of glutathione (oxidized form), L-cysteic acid or L-

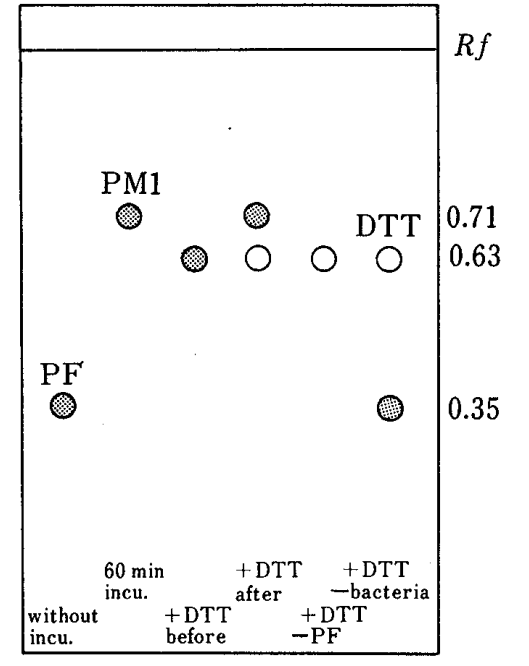

Fig. 1. Adduct Formation with Dithiothreitol

L. brevis was incubated with paeoniflorin (PF) for $1 \mathrm{~h}$ at $37^{\circ} \mathrm{C}$ as described in Materials and Methods. Dithiothreitol (DTT) at a final concentration of $5 \mathrm{~mm}$ was added to the reaction mixture before (+DTT, before) or after incubation (+DTT, after). In the latter case, the mixture was incubated for a further $30 \mathrm{~min}$. Control experiments were carried out in the absence of PF (+DTT, -PE) and bacteria (+DTT, - bacteria). Open and shaded circles indicate yellowish spots of DTT and pink-colored spots, respectively. PM1, paeonimetabolin I.

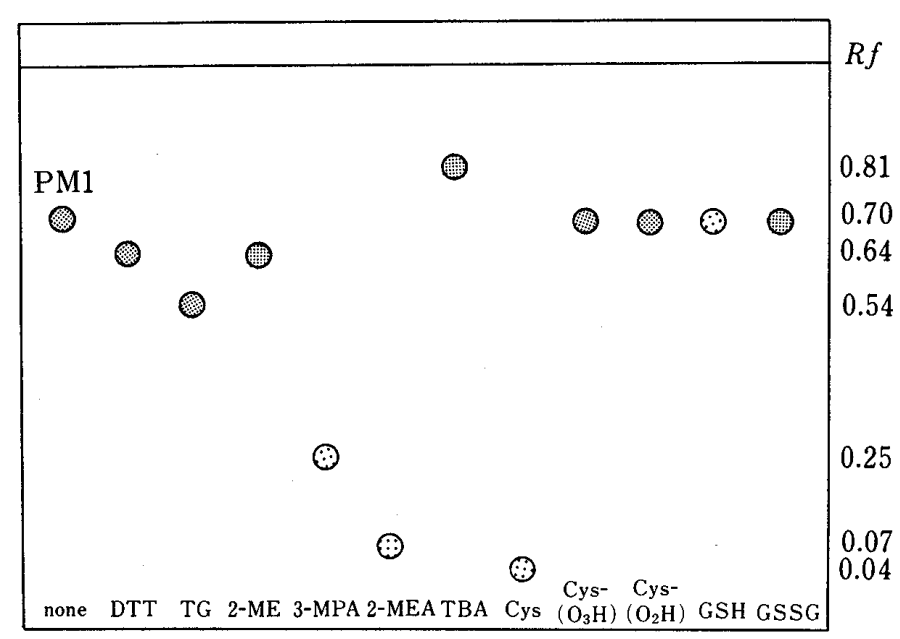

Fig. 2. Effect of Various Sulfhydryl Compounds on the Metabolism of Paeoniflorin

L. brevis was incubated with paeoniflorin in the presence of $5 \mathrm{mM}$ DTT, 1-thioglycerol (TG), 2-mercaptoethanol (2-ME), 3-mercaptopropionic acid (3MPA), 2-mercaptoethylamine (2-MEA), thiobenzoic acid (TBA), L-cysteine (Cys), L-cysteic acid (Cys$\left(\mathrm{O}_{3} \mathrm{H}\right)$ ), L-cysteinesulfinic acid $\left(\mathrm{Cys}\left(\mathrm{O}_{2} \mathrm{H}\right)\right)$ or glutathione, reduced form (GSH) or oxidized form (GSSG) for $1 \mathrm{~h}$ at $37^{\circ} \mathrm{C}$. Shaded and dotted circles indicate intensely and feebly pink-colored spots, respectively. 

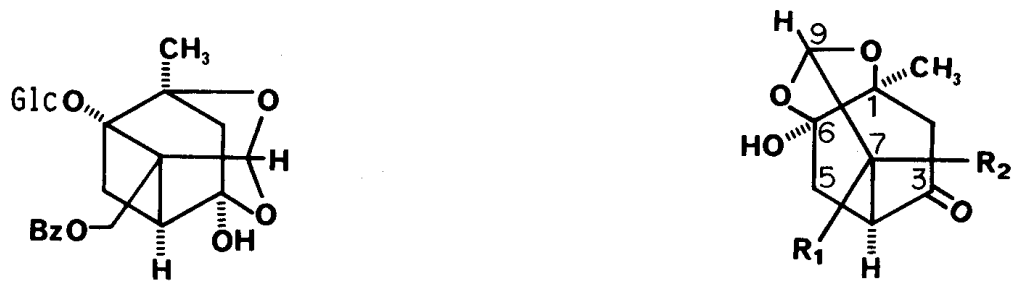

$$
\begin{array}{rrll}
\mathbf{2}: & \mathrm{R}_{1}=-\mathrm{CH}_{3}, \mathrm{R}_{2}=-\mathrm{H} & \mathbf{6}: & \mathrm{R}_{1}=-\mathrm{CH}_{2} \mathrm{SCH}_{2} \mathrm{CH}_{2} \mathrm{OH}, \mathrm{R}_{2}=-\mathrm{H} \\
\mathbf{3}: & \mathrm{R}_{1}=-\mathrm{H}, \mathrm{R}_{2}=-\mathrm{CH}_{3} & \mathbf{7}: & \mathrm{R}_{1}=-\mathrm{H}, \mathrm{R}_{2}=-\mathrm{CH}_{2} \mathrm{SCH}_{2} \mathrm{CH}_{2} \mathrm{OH} \\
\mathbf{4}: & \mathrm{R}_{1}=-\mathrm{CH}_{2} \mathrm{SCH}_{2} \mathrm{CH}_{2} \mathrm{COOH}_{2} \mathrm{R}_{2}=-\mathrm{H} & \mathbf{8}: & \mathrm{R}_{1}=-\mathrm{CH}_{2} \mathrm{SCOC}_{6} \mathrm{H}_{5}, \mathrm{R}_{2}=-\mathrm{H} \\
\mathbf{5}: & \mathrm{R}_{1}=-\mathrm{H}, \mathrm{R}_{2}=-\mathrm{CH}_{2} \mathrm{SCH}_{2} \mathrm{CH}_{2} \mathrm{COOH} & \mathbf{9}: & \mathrm{R}_{1}=-\mathrm{H}, \mathrm{R}_{2}=-\mathrm{CH}_{2} \mathrm{SCOC}_{6} \mathrm{H}_{5} \\
& \mathbf{1 0}: & \mathrm{R}_{1}=-\mathrm{H}, \mathrm{R}_{2}=-\mathrm{CH}_{2} \mathrm{OCOC}_{6} \mathrm{H}_{5}
\end{array}
$$

Chart 1. Structures of Paeoniflorin and Paeonimetabolin I Derivatives Listed in the Paper

cysteinesulfinic acid did not affect the amounts of paeonimetabolin I ( 2 and 3 ) formed, and no new products were formed. Moreover, when new products obtained in the presence of dithiothreitol (having two sulfhydryl groups) were treated with $p$-chloromercuribenzoic acid, the products were converted to other compounds. However, the products obtained in the presence of 1-thioglycerol (having one sulfhydryl group) were not converted by treatment with $p$-chloromercuribenzoic acid.

These results suggest that an intermediate in the metabolism of $\mathbf{1}$ forms adducts with various sulfhydryl compounds, and the sulfhydryl group takes part in the adduct formation.

\section{Structures of Adducts}

Following incubation of 1 with a suspension of $L$. brevis in the presence of 3mercaptopropionic acid, 2-mercaptoethanol and thiobenzoic acid, major products were extracted and separated into two isomers, 4 and 5, 6 and 7, and 8 and 9, respectively, by repeated column chromatography. The structures of these isomers were characterized as follows.

(HOOC- $\left.-\mathrm{CH}_{2}-\mathrm{CH}_{2}-\mathrm{SH}\right) \cdot$ Adducts (4 and 5) Products 4 and 5 were obtained as colorless oils. The molecular formulae were determined to be $\mathrm{C}_{13} \mathrm{H}_{18} \mathrm{O}_{6} \mathrm{~S}$ by high-resolution MS. The ${ }^{1} \mathrm{H}$ - and ${ }^{13} \mathrm{C}-\mathrm{NMR}$ spectra (Tables I and II) of 4 and 5 were quite similar to those of 2 and 3 , respectively, except for the signals due to the presence of a HOOC $-\mathrm{CH}_{2}-\mathrm{CH}_{2}-\mathrm{S}-\mathrm{CH}_{2}-$ group instead of a methyl signal $(8-\mathrm{H})$ in the latter two, thus indicating that 4 and 5 are an isomeric mixture of 8-(2-carboxyethylthio)paeonimetabolin I. The configuration around at C-7 was deduced on the basis of the presence or absence of $\gamma$ gauche steric effect ${ }^{6)}$ at the C-5 and C-8 signals in the ${ }^{13} \mathrm{C}-\mathrm{NMR}$ spectra, as observed in 2 . The signal of $\mathrm{C}-5$ in $\mathbf{4}$ appeared at $\delta 31.3,4.2 \mathrm{ppm}$ units higher than that in $\mathbf{5}(\delta 35.5)$, indicating the $\gamma$-gauche effect in 4 . These findings led us to conclude the structures of $\mathbf{4}$ and 5 to be $(7 S)$ - and (7R)-8-(2-carboxyethylthio)paeonimetabolin I (Chart 1), respectively.

(HO- $\left.-\mathrm{CH}_{2}-\mathrm{CH}_{2}-\mathbf{S H}\right) \cdot$ Adducts (6 and 7) - Both 6 and 7 were obtained as colorless oils with the same molecular formula, $\mathrm{C}_{12} \mathrm{H}_{18} \mathrm{O}_{5} \mathrm{~S}$. The ${ }^{1} \mathrm{H}$ - and ${ }^{13} \mathrm{C}-\mathrm{NMR}$ spectra (Tables I and II) were indicative of paeonimetabolin I derivatives in which a $\mathrm{HO}-\mathrm{CH}_{2}-\mathrm{CH}_{2}-\mathrm{S}$-group is attached to the $\mathrm{C}-8$ position. On the basis of the presence or absence of $\gamma$-gauche steric effect between C-5 ( $\delta 31.5$ and 35.6 in 6 and 7, respectively) and C-8 the structures of 6 and 7 were concluded to be $(7 S)$ - and (7R)-8-(2-hydroxyethylthio)paeonimetabolin I (Chart 1), respectively.

$\left(\mathrm{C}_{6} \mathrm{H}_{5}-\mathrm{CO}-\mathrm{SH}\right) \cdot$ Adducts $(8$ and 9)-Similarly, oily products with the molecular formula, $\mathrm{C}_{17} \mathrm{H}_{18} \mathrm{O}_{5} \mathrm{~S}$, were concluded to be $(7 S)$ - and (7R)-8-benzoylthiopaeonimetabolin I (Chart 1), respectively, by ${ }^{1} \mathrm{H}$ - and ${ }^{13} \mathrm{C}-\mathrm{NMR}$ analyses (Tables I and II). The (7R)-isomer showed spectroscopic properties quite similar to those of naturally occuring paeoniflori- 
Table I. ${ }^{1} \mathrm{H}-\mathrm{NMR}(270 \mathrm{MHz})$ Spectral Data of Adducts (ppm in Pyridine- $\left.d_{5}\right)^{a)}$

\begin{tabular}{|c|c|c|c|c|c|c|}
\hline & $\begin{array}{c}4 \\
7 S\end{array}$ & $\begin{array}{c}5 \\
7 R\end{array}$ & $\begin{array}{c}\mathbf{6} \\
7 S\end{array}$ & $\begin{array}{c}7 \\
7 R\end{array}$ & $\begin{array}{c}8 \\
7 S^{b)}\end{array}$ & $\begin{array}{c}9 \\
7 R^{b)}\end{array}$ \\
\hline $2-\mathrm{H}_{2}$ & $\begin{array}{l}2.97,3.03, \mathrm{ABq} \\
(16.8)\end{array}$ & $\begin{array}{l}3.00,3.07, \mathrm{ABq} \\
(16.8)\end{array}$ & $\begin{array}{l}2.90,2.96, \mathrm{ABq} \\
(17.1)\end{array}$ & $\begin{array}{l}2.89,2.96, \mathrm{ABq} \\
(16.9)\end{array}$ & $\begin{array}{l}2.67,2.74, \mathrm{ABq} \\
(17.2)\end{array}$ & $2.68, \mathrm{~s}$ \\
\hline $4-\mathrm{H}$ & $2.97, \mathrm{~m}$ & $3.00, \mathrm{~m}$ & $2.92, \mathrm{~m}$ & $2.92, \mathrm{~m}$ & $2.75, \mathrm{~m}$ & $2.97, \mathrm{~m}$ \\
\hline $5-\mathrm{H}_{2}$ & $\begin{array}{l}2.32, \mathrm{dd} ; 2.58 \\
\text { dd }(13.7,1.8 \\
13.7,3.0)\end{array}$ & $\begin{array}{l}2.42, \mathrm{dd} ; 2.53 \\
\mathrm{dd}(13.7,2.4 \\
13.7,3.0)\end{array}$ & $\begin{array}{l}2.27, \mathrm{dd} ; 2.54 \\
\mathrm{dd}(13.7,2.2 \\
13.7,3.4)\end{array}$ & $\begin{array}{l}2.34, \mathrm{dd} ; 2.48 \\
\mathrm{dd}(13.4,2.4 \\
13.4,3.2)\end{array}$ & $\begin{array}{l}2.11, \mathrm{dd} ; 2.56 \\
\mathrm{dd}(13.9,2.3 ; \\
13.9,3.2)\end{array}$ & $\begin{array}{l}2.20, \mathrm{dd} ; 2.55 \\
\mathrm{dd}(13.6,2.7 \\
13.6,3.4)\end{array}$ \\
\hline 7-H & $\begin{array}{l}2.08, \mathrm{t} \\
(7.8)\end{array}$ & $2.24, \mathrm{~m}$ & $\begin{array}{l}2.02, \mathrm{t} \\
(7.8)\end{array}$ & $2.20, \mathrm{~m}$ & $\begin{array}{l}1.96, \mathrm{t} \\
(7.7)\end{array}$ & $\begin{array}{l}2.22, \mathrm{td} \\
(7.3,1.0)\end{array}$ \\
\hline $8-\mathrm{H}_{2}$ & $\begin{array}{l}2.71, \mathrm{dd} ; 2.93 \\
\mathrm{dd}(14.0,7.8 \\
14.0,7.8)\end{array}$ & $2.60-2.90, \mathrm{~m}$ & $\begin{array}{l}2.67, \mathrm{dd} ; 2.92 \\
\mathrm{dd}(13.4,7.8 \\
13.4,7.8)\end{array}$ & $\begin{array}{l}2.68, \mathrm{dd} ; 2.91 \\
\text { dd }(13.3,8.3 \\
13.3,7.6)\end{array}$ & $\begin{array}{l}3.22, \mathrm{~d} \\
(7.7)\end{array}$ & $\begin{array}{l}2.95, \mathrm{~d} \\
(7.3)\end{array}$ \\
\hline $9-\mathrm{H}$ & 5.69, br s & 5.74, br s & 5.62, brs & 5.69, brs & 5.39, br s & 5.41 , brs \\
\hline $10-\mathrm{H}_{3}$ & $\begin{array}{l}1.48, \mathrm{~s} \\
-\mathrm{CH}_{2} \mathrm{COOH}, \\
2.77, \mathrm{t}(6.6) \\
-\mathrm{CH}_{2} \mathrm{~S}-, 2.92, \\
\mathrm{t}(6.6)\end{array}$ & $\begin{array}{l}1.51, \mathrm{~s} \\
-\mathrm{CH}_{2} \mathrm{COOH}, \\
2.81, \mathrm{t}(6.6) \\
-\mathrm{C}_{2} \mathrm{~S}-, 2.95, \\
\mathrm{t}(6.6)\end{array}$ & $\begin{array}{l}1.45, \mathrm{~s} \\
-\mathrm{CH}_{2} \mathrm{~S}-, 2.78 \\
\mathrm{td}(6.6,1.9) \\
-\mathrm{C}_{2} \mathrm{OH}, 3.90 \\
\mathrm{t}(6.6)\end{array}$ & $\begin{array}{l}1.45, \mathrm{~s} \\
-\mathrm{CH}_{2} \mathrm{~S}-, 2.78 \\
\mathrm{td}(6.6,1.9) \\
-\mathrm{CH}_{2} \mathrm{OH}, 3.90 \\
\mathrm{t}(6.6)\end{array}$ & $\begin{array}{l}1.31, \mathrm{~s} \\
3^{\prime}, 5^{\prime}-\mathrm{H}, 7.45, \\
\text { brt }(7.6) \\
4^{\prime}-\mathrm{H}, 7.59, \text { br t } \\
(7.6) \\
2^{\prime}, 6^{\prime}-\mathrm{H}, 7.96, \\
\text { brd }(7.6)\end{array}$ & $\begin{array}{l}1.32, \mathrm{~s} \\
3^{\prime}, 5^{\prime}-\mathrm{H}, 7.45, \\
\text { br t }(7.6) \\
4^{\prime}-\mathrm{H}, 7.59, \text { br t } \\
(7.6) \\
2^{\prime}, 6^{\prime}-\mathrm{H}, 7.96, \\
\text { brd }(7.6)\end{array}$ \\
\hline
\end{tabular}

a) Coupling constants $(\mathrm{Hz})$ are shown in parentheses. b) Measured in $\mathrm{CDCl}_{3}$.

TABLE II. ${ }^{13} \mathrm{C}-\mathrm{NMR}\left(22.5 \mathrm{MHz}\right.$ ) Spectral Data of Adducts and Paeonimetabolin I (ppm in Pyridine- $d_{5}$ )

\begin{tabular}{|c|c|c|c|c|c|c|c|c|}
\hline $\begin{array}{c}\text { Carbon } \\
\text { No. }\end{array}$ & $\begin{array}{c}4 \\
7 S\end{array}$ & $\begin{array}{c}5 \\
7 R\end{array}$ & $\begin{array}{c}6 \\
7 S\end{array}$ & $\begin{array}{c}7 \\
7 R\end{array}$ & $\begin{array}{c}8 \\
7 S^{a)}\end{array}$ & $\begin{array}{c}9 \\
7 R^{a)}\end{array}$ & $\begin{array}{c}2 \\
7 S^{a)}\end{array}$ & $\begin{array}{c}3 \\
7 R^{a)}\end{array}$ \\
\hline C-1 & $78.3(\mathrm{~s})$ & $79.1(\mathrm{~s})$ & $78.5(\mathrm{~s})$ & $79.0(\mathrm{~s})$ & $78.0(\mathrm{~s})$ & $78.6(\mathrm{~s})$ & 77.4 (s) & $78.3(\mathrm{~s})$ \\
\hline C-2 & $47.9(\mathrm{t})$ & $47.6(\mathrm{t})$ & $48.0(\mathrm{t})$ & $47.4(\mathrm{t})$ & $47.4(\mathrm{t})$ & $46.8(\mathrm{t})$ & $47.5(t)$ & $46.8(t)$ \\
\hline C-3 & 210.9 (s) & $210.4(\mathrm{~s})$ & $211.1(\mathrm{~s})$ & $210.4(\mathrm{~s})$ & $210.5(\mathrm{~s})$ & $210.2(\mathrm{~s})$ & $210.9(\mathrm{~s})$ & $210.1(\mathrm{~s})$ \\
\hline C-4 & 47.8 (d) & 48.8 (d) & $48: 1$ (d) & 48.7 (d) & 47.4 (d) & 47.8 (d) & $50.2(\mathrm{~d})$ & 49.6 (d) \\
\hline C-5 & $31.3(\mathrm{t})$ & $35.5(\mathrm{t})$ & $31.7(t)$ & $35.6(\mathrm{t})$ & $30.8(\mathrm{t})$ & $34.2(\mathrm{t})$ & $30.4(\mathrm{t})$ & $34.3(\mathrm{t})$ \\
\hline$C-6$ & $102.2(\mathrm{~s})$ & $102.2(\mathrm{~s})$ & $102.3(\mathrm{~s})$ & $102.0(\mathrm{~s})$ & $101.7(\mathrm{~s})$ & $101.5(\mathrm{~s})$ & $101.6(\mathrm{~s})$ & $101.3(\mathrm{~s})$ \\
\hline C-7 & 43.1 (d) & 44.3 (d) & $43.6(\mathrm{~d})$ & 44.4 (d) & 43.3 (d) & 44.1 (d) & 37.9 (d) & 38.4 (d) \\
\hline C-8 & $31.3(\mathrm{t})$ & $31.3(\mathrm{t})$ & $31.7(\mathrm{t})$ & $31.3(\mathrm{t})$ & $27.7(\mathrm{t})$ & $27.2(\mathrm{t})$ & $14.6(q)$ & $13.3(q)$ \\
\hline C-9 & $101.2(\mathrm{~d})$ & $101.0(\mathrm{~d})$ & $101.4(\mathrm{~d})$ & $100.0(\mathrm{~d})$ & $101.1(\mathrm{~d})$ & $100.8(d)$ & 103.1 (d) & $103.0(d)$ \\
\hline C- 10 & $21.7(q)$ & $22.0(\mathrm{q})$ & $21.7(q)$ & $21.7(q)$ & $20.9(q)$ & $20.9(q)$ & $20.9(q)$ & $21.1(\mathrm{q})$ \\
\hline$-\mathrm{CH}_{2} \mathrm{~S}-$ & $35.1(\mathrm{t})$ & $35.5(\mathrm{t})$ & $35.2(\mathrm{t})$ & $35.4(\mathrm{t})$ & & & & \\
\hline$-\overline{\mathrm{C}} \mathrm{H}_{2}-$ & $27.3(\mathrm{t})$ & $28.1(\mathrm{t})$ & $61.6(t)$ & $61.6(t)$ & & & & \\
\hline$-\mathrm{COOH}$ & $173.9(\mathrm{~s})$ & $174.2(\mathrm{~s})$ & & & & & & \\
\hline \multirow[t]{5}{*}{$\underline{\mathrm{C}}_{6} \mathrm{H}_{5} \underline{\mathrm{COS}}-$} & & & & & $127.1(\mathrm{~d})$ & $127.1(\mathrm{~d})$ & & \\
\hline & & & & & $128.5(\mathrm{~d})$ & 128.1 (d) & & \\
\hline & & & & & $133.5(\mathrm{~d})$ & 133.5 (d) & & \\
\hline & & & & & $136.3(\mathrm{~s})$ & $136.4(\mathrm{~s})$ & & \\
\hline & & & & & $190.9(\mathrm{~s})$ & $191.3(\mathrm{~s})$ & & \\
\hline
\end{tabular}

Abbreviations given in parentheses indicate the signal patterns based on the OFR and INEPT methods. a) Measured in $\mathrm{CDCl}_{3}$.

genone (10), ${ }^{77}$ which could be regarded as a benzoic acid/paeonimetabolin-I adduct.

\section{Discussion}

Paeoniflorin (1) was transformed to new products by L. brevis in the presence of various 


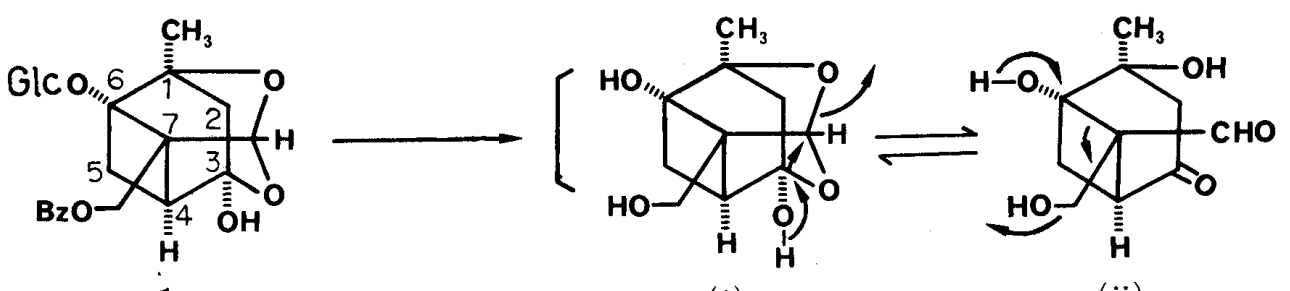

(i)

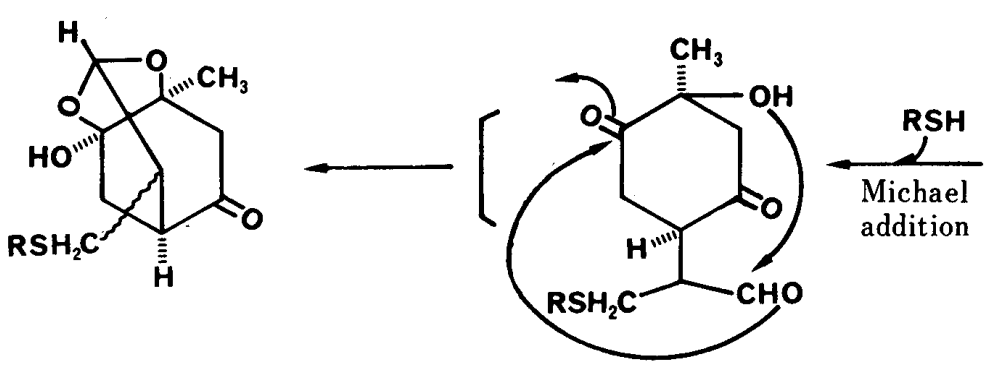

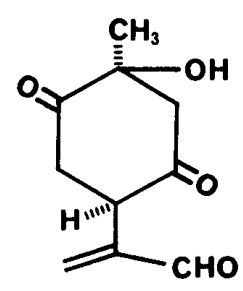

(iii)

Chart 2. Processes for Formation of Adducts in the Presence of Sulfhydryl Compounds

sulfhydryl compounds. These products possessed similar structures in which the sulfhydryl compounds are covalently bound at the C-8 position of paeonimetabolin I ( 2 and 3 ) through a thioether linkage. They could not be formed by incubation of paeonimetabolin I ( 2 and 3 ) with sulfhydryl compounds, nor in the absence of $L$. brevis. The mechanism of formation of the new products seems to be that an $\alpha, \beta$-unsaturated aldehyde intermediate (iii in Chart 2) in the metabolic processes of 1 to paeonimetabolin I ( 2 and 3 ), as we proposed in the preceding papers ${ }^{1,3)}$ reacts in preference with a mercapto group of the compounds by Michael addition, followed by the formation of a hemiketal-acetal system. Thus, the adducts obtained contained the $S$ - and $R$-isomers, which were formed in almost equal amounts in the presence of 3-mercaptopropionic acid, 2-mercaptoethanol and thiobenzoic acid. Among nucleophilic functional groups of the compounds, only mercapto and mercaptocarbonyl groups took part in the reaction; hydroxy, carboxy and amino groups were less reactive.

On the other hand, compound 9 could be regarded as an analogue of paeoniflorigenone $(10)^{7)}$ in which the benzoyl moiety is replaced by a thiobenzoyl group. The formation of this adduct from the metabolic intermediate (iii) in the presence of thiobenzoic acid suggests a similar pathway for biosynthesis of paeoniflorigenone (10) in peonies.

Acknowledgement This study was funded in part by Tsumura Juntendo Co., Ltd. (Tokyo).

\section{References and Notes}

1) M. Hattori, Y. Z. Shu, M. Shimizu, T. Hayashi, N. Morita, K. Kobashi, G. J. Xu and T. Namba, Chem. Pharm. Bull., 33, 3838 (1985).

2) A tentative name "paeonimetaboline I" used in the previous papers ${ }^{1,3,4}$ was revised to "paeonimetabolin I" to avoid confusion, as it does not contain a nitrogen atom in the molecule.

3) Y. Z. Shu, M. Hattori, T. Akao, K. Kobashi, K. Kagei, K. Fukuyama, T. Tsukihara and T. Namba, Chem. Pharm. Bull., 35, 3726 (1987).

4) Y. Z. Shu, M. Hattori, T. Akao, K. Kobashi and T. Namba, J. Med. Pharm. Wakan-Yaku, 4, 82 (1987).

5) M. Kaneda, Y. Iitaka and S. Shibata, Tetrahedron, 28, 4309 (1972).

6) E. Breitmaier and W. Voelter, " ${ }^{13}$ C-NMR Spectroscopy," 2nd Edition, Verlag Chemie, Weinheim-New York, 1978, pp. 74-75.

7) M. Shimizu, T. Hayashi, N. Morita, F. Kiuchi, H. Noguchi, Y. Iitaka and U. Sankawa, Chem. Pharm. Bull., 31, 577 (1983). 